\title{
QUEEN VICTORIA'S MEDICAL HOUSEHOLD
}

\author{
by
}

\section{A. M. COOKE*}

On the 24th of May, 1819, at Kensington Palace it was announced that:

Her Royal Highness the Duchess of Kent was safely delivered of a Princess this morning at a quarter past five o'clock. Her Royal Highness and the Princess are doing well.

D. D. Davis
J. Wilson

DRS. DAVIS AND WILSON were the first of a long line of medical men who attended, or were appointed to attend, Queen Victoria throughout her lifetime of nearly eighty-two years. Also assisting at the birth was a midwife, Fräulein Siebold, who, although she also held a medical qualification, did not sign the bulletin. It is an interesting coincidence that the Fräulein also attended at the birth of Prince Albert.

We do not know what other medical attendants Victoria had as a child or before she came to the throne, but we know the medical staff of her father and mother. When ill, doubtless she would have been attended by one of them.

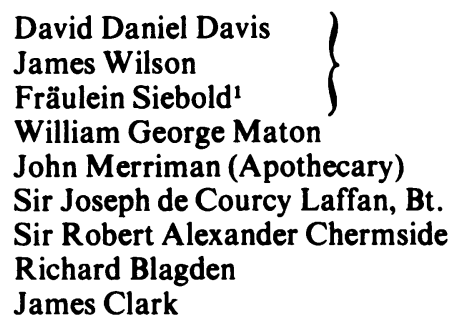

Date of death
1841
$?$
$?$
1835
1839
1848
1860
1861
1870

As a girl Victoria was kept strictly under her mother's thumb, was told that she was inexperienced and immature, and that she would require much help when she came to the throne. This is thought to have been part of a plan by her mother and her mother's Comptroller, Sir John Conroy, to make her mother Regent. In the event, things were very different. On her accession at the age of eighteen, the Queen immediately asserted herself, ceased to sleep in her mother's bedroom, dismissed Sir John Conroy, whom she very much disliked, held a Privy Council with such dignity and poise that all were charmed, interviewed a number of Ministers and officials, wrote four long letters; and after dinner appointed Dr. James Clark as her first physician. ${ }^{2}$ Later, she

* A. M. Cooke, M.A., D.M., F.R.C.P., Merton College, Oxford.

\footnotetext{
${ }^{1}$ Her date of death is not known. She was still alive (and married, as Frau Heidenreich) in 1845, when Queen Victoria met her in Germany.

2 Elizabeth Longford, Victoria RI, London, Weidenfeld \& Nicolson, 1964.
} 


\section{A. M. Cooke}

appointed the rest of her Medical Household, twenty-five in England and five in Scotland. The large number of the former was due to reappointment of eleven from King William's household, no doubt from a desire not to offend elderly and loyal retainers. The situation was different in Ireland. Had the Queen needed medical aid when in Dublin, she would probably have turned to the Lord Lieutenant's staff, the State Physician, State Surgeon, State Apothecary, and State Dentist. The titles of these officers were changed in 1852 to Physician-in-Ordinary, Surgeon-in-Ordinary, etc. The first physician in Ireland to be appointed to the Queen rather than to the Lord Lieutenant was Sir Dominic Corrigan in 1847, doubtless in anticipation of the Queen's first visit to Dublin in 1849. The first surgical appointment of a similar kind was that of James William Cusack in 1859.

Throughout her life, Queen Victoria never appointed a woman doctor to her staff. She did not approve of women studying for any profession, and in particular for that of medicine. She wrote of the "awful idea of allowing young girls and young men to enter the dissecting room together, where the young girls would have to study things which could not be named before them". ${ }^{3}$ It is of interest that at one time the University of Oxford held similar views to those of the Queen. From 1917 to 1934, in the Department of Human Anatomy there was a separate dissecting room for female students, with a female instructor.

\section{SELECTION}

The methods by which members of the medical household were selected are obscure. Some, we know, were promoted from the lower grades. It is probable that some names were suggested by their predecessors, or were recommended by the Presidents of the various Royal Colleges, or by members of the Royal Household. The arrangements were different in Ireland (see below). However selected, these medical men were mostly recognized as leaders of their profession. At least fifty-seven were at some time Presidents of the appropriate Royal Colleges. Forty-two were Fellows of the Royal Society, including two Presidents, Lord Lister and Sir Benjamin Collins Brodie.

\section{APPOINTMENT}

The procedure for the appointment of the Medical Household, as for other Household Officers, was governed by an Act of Parliament passed in 1536 (27 Henry VIII, c. 11) and so was, not surprisingly, cumbersome. All appointments to the Royal Household, from the Captain of the Honourable Corps of Gentlemen at Arms and Ladies of the Bedchamber to watermen and chimney-sweeps, were made under a Warrant issued by the Lord Chamberlain, with the resounding prose of a legal document.

To have hold exercise and enjoy the said Place together with all Rights Profits Privileges and Advantages thereunto belonging And for so doing this shall be your Warrant Given under my hand and Seal this 24th day of July in the ... year of Her Majesty's Reign.

The Warrants were nearly all signed by the Lord Chamberlain or by the Comptroller

${ }^{3}$ Ibid., 


\section{Queen Victoria's Medical Household}

of the Household on his instructions, but a few by the Keeper of the Privy Purse. The Warrants did not specify any term of office, and most holders continued until death or retirement.

All the Warrants required Stamp Duty, which seemed to vary partly with the importance of the office and partly with the stipend. Some examples are:

$\begin{array}{lr}\text { Lord Chamberlain } & £ 100 \\ \text { Lord in Waiting } & 35 \\ \text { Examiner of Plays } & 25 \\ \text { Master of the Music } & 12 \\ \text { Physician } & 12 \\ \text { Surveyor of Pictures } & 6 \\ \text { Bargemaster } & 4 \\ \text { Poet Laureate } & 4 \\ \text { Waterman } & 2\end{array}$

The Stamp Duty was itself complicated. For example, that of one official was made up as follows:

\begin{tabular}{|c|c|}
\hline $\begin{array}{l}\text { Fees to Lord Chancellor } \\
\text { Fees (illegible) } \\
\text { Sealers } \\
\text { Clerk of the Hanaper } \\
\text { Deputy Clerk of the Hanaper } \\
\text { Engrossing of patent on ornamental skin } \\
\text { Boxes } \\
\text { Stamp }\end{array}$ & $\begin{array}{r}£ 1.11 .4 \\
3.11 .6 \\
10.6 \\
6.13 .4 \\
10.6 \\
1.1 .0 \\
9.6 \\
2.0 \\
\end{array}$ \\
\hline & $£ 14.9 .8$ \\
\hline
\end{tabular}

The old procedure continued until 1851, when another Act was passed (14 and 15 Victoria, c. 82) "to simplify the Forms of Appointment to Certain Offices, and the manner of passing grants under the Great Seal".

In 1867, it was ruled that no Warrants were to be issued unless requested, which meant that the considerable Stamp Duty could be avoided by those who wished to do so. On the accession of Edward VII in 1901, the procedure was changed again to two forms of Warrant, one for officers and one for servants.

\section{SOURCES}

It might appear at first sight a simple matter to compile a list of all Queen Victoria's medical attendants, but there are a number of sources of information which are sometimes incomplete and often conflict on dates and other particulars. Copies of the Lord Chamberlain's Warrants of Appointment are to be found in the Public Record Office, and must be accounted the primary and most accurate source, but they are incomplete and contain a few errors. For example, John Scott in 1838 was appointed as a surgeon, but he was undoubtedly a physician. The next most important source is an annual publication The Royal Calendar and Court and City Register for England, Scotland, Ireland and the Colonies.... In 1894, the name was changed to

- The Hanaper was a basket or container in which sealed documents were placed. 


\section{A. M. Cooke}

The British Imperial Calendar and Civil Service List, or General Register of the United Kingdom of Great Britain and Ireland, and the Colonies.... The third important source is Dr. Samuel Dodd Clippingdale's Medical Court Roll, a holograph manuscript in the library of the Royal College of Surgeons of England, listing the medical attendants of the Sovereigns and Royal Family from William I to George V, a remarkable compilation covering 850 years. Information has also been sought from the Dictionary of National Biography; William Munk's Roll of the Royal College of Physicians of London, vol. 4: 1826-1925, London, Royal College of Physicians, 1955; Victor Plarr's Lives of the Fellows of the Royal College of Surgeons of England, 2 vols., London, Royal College of Surgeons, 1930; W. S. Craig's History of the Royal College of Physicians of Edinburgh, Oxford, Blackwell Scientific Publications, 1976; Sir Charles Cameron's History of the Royal College of Surgeons in Ireland and of the Irish Schools of Medicine, Dublin, Fannin, 1886; Leslie G. Matthews's The royal apothecaries, London, Wellcome Institute, 1967; the Medical Directory (from 1877); and obituaries in the Lancet, British Medical Journal, Edinburgh Medical Journal, and the Dublin Journal of Medical Science. Where there was conflict on dates and other facts, I have chosen the date or fact which accords best with the other evidence, such as the date of death or retirement of the appointee's predecessor.

\section{THE GRADES OF MEDICAL ATTENDANT}

In England and Scotland, the Physicians- and Surgeons-in-Ordinary were the consultants to the Queen, but at times acted as her general practitioners. Like other patients, she had likes and dislikes, and naturally her attendants conformed to her wishes. The senior of the physicians was styled Head of the Medical Department and the senior of the Surgeons as Sergeant Surgeon. There were variable numbers in these offices, the usual being three physicians and three surgeons, so that in an emergency there would be at least one available. Various specialists, accoucheurs, oculists, and aurists are included in the lists of physicians or surgeons.

The second grade was that of the Physicians and Surgeons Extraordinary. They formed a second line and were in a sense on probation. Many, but not all, were in due time promoted to being in-Ordinary. A few of those in-Ordinary, usually because they had become incapacitated by age or ill health, reverted to being Extraordinary. This was a compliment paid for long service.

The next grade included the Physician to the Household and the Surgeon to the Household, who were the consultants to the Household up to but not including the Royal Family.

Then came the Apothecaries, mostly in England. This branch of the profession had originally prepared and dispensed drugs, but since the Apothecaries Act of 1815 had become general practitioners. For the Queen's Apothecaries the nomenclature was variable and the duties not always clearly defined. Sometimes styled Apothecary to the Household, and from 1864 Surgeon and Apothecary or Surgeon Apothecary, they were general practitioners, and were of two classes. There were Apothecaries to the Household, who acted as general practitioners to the Royal Household up to but not including the Royal Family, and Apothecaries to the Person who acted as general 


\section{Queen Victoria's Medical Household}

practitioners to the Queen. Often the two offices were held by the same man. For example, in 1837, John Nussey and Edward Duke Moore were Apothecaries to the Person, while John Nussey and Charles Craddock were Apothecaries to the Household. The Apothecaries, despite their name, did not dispense medicines. There were Pharmacists appointed to "Her Majesty's Establishment" in England and Scotland, and in Ireland as "State Apothecaries". A list is appended to the main lists.

The Physicians- and Surgeons-in-Ordinary were senior men when appointed, and served for an average period of only twelve years. The Apothecaries were much younger when appointed, and served for an average of twenty-two years, and some for over forty years. The Apothecaries were appointed in pairs, and were local general practitioners, often with family connexions. The family of John Nussey (1799-1862) had been Apothecaries to the Royal Family and Household for over 100 years. The Merrimans were a father and two sons, the Ellisons a father and son, the Fairbanks two brothers, and the Hoffmeisters a father and four sons.

The Lord Chamberlain's Warrants sometimes specify the place of the Apothecary's appointment, such as Windsor, Kensington, Osborne, or Brighton, but at other times merely state "to the Household". The last probably meant to Buckingham Palace, but the Queen did not like this palace and mostly resided at Windsor or Osborne.

In Scotland, there were no appointments as Apothecaries, but there were Resident Physicians at Balmoral, who fulfilled much the same functions.

In Ireland, the members of the Medical Household were appointed some to the Queen and some to the Lord Lieutenants, who often served for only short periods and tended to appoint their own personal medical attendants. Also, the distinction between physicians and surgeons, and that between those appointed in-Ordinary and those to the Household was blurred. George William Hatchell was appointed as a surgeon in 1838 and as a physician in 1857.

As well as the lists of Physicians, Surgeons, and Apothecaries, which follow there is a small list, marked "Miscellaneous", of doctors who rendered various services to Queen Victoria, but were not on the Medical Household. There were also a number of Honorary Physicians and Surgeons who appear in the lists of medical attendants. These appointments were given to distinguished medical men, usually those who had served in the Royal Navy, Army, India, or in Public Health. The title was purely honorary, and they had no medical duties. One Director-General of the Army Medical Department, Sir James McGrigor, Bart., who held this office for thirty-four years, never became an Honorary Physician, but did become an Extraordinary Physician to the Queen for nineteen years.

There was a Dental Household in England, Scotland, and Ireland. Finally, there are lists of various paramedical personnel and of pharmacists who rendered service to Queen Victoria.

\section{PAYMENTS}

Information on this subject is scanty. At the beginning of the reign, payments to the Medical Household in England varied, but were similar for each grade, which suggests that they were retaining fees rather than for items of service rendered. The Physicians- and Surgeons-in-Ordinary received a nominal $£ 300$ per annum, but 


\section{A. M. Cooke}

deductions for fees and Stamp Duty reduced the amount to about $£ 213$. The Surgeon to the Household received $£ 400$, and the Apothecaries about $£ 550$, no doubt because their duties were more arduous. In Scotland, a fee of $£ 50$ for the Second Physician is mentioned, but this was discontinued in 1844. In Ireland, the State Surgeon received $£ 13313 s$. $4 d$., later reduced to $£ 100$. As well as these retaining fees, there may have been payments for services rendered. Indeed, Robert Keate, who became Surgeon-inOrdinary to Queen Victoria in 1837, at the age of sixty, is reported to have said "I have attended four Sovereigns, and have been badly paid for my services. One of them, now deceased, owed me nine thousand guineas." On the other hand, in 1868, one of the Apothecaries, Dr. Thomas Fairbank, submitted an account of $£ 2117 \mathrm{~s} .6 \mathrm{~d}$. for attendance on the Queen and the Royal Children. This was disallowed on the grounds that it was provided for in his stipend of $£ 200$.

The Lord Chamberlain's Expenditure Books are little help, because they are not account books in the ordinary sense of the word, but letter books, that is correspondence to and from the Lord Chamberlain's department about stipends, pensions, and appointments. In 1868, there are two entries which suggest that the total cost of the Medical Household was about $£ 2,254$ per annum. As there was little inflation in Queen Victoria's reign, medical stipends did not rise significantly. Income tax was reintroduced in 1842 at sevenpence in the pound, and at the end of the reign was eightpence. The penny post, introduced in 1840 , was unchanged sixty years later.

How much did the Queen use her doctors? She was, in general, healthy. She required the care of Sir Charles Locock and Robert Ferguson for her nine uncomplicated pregnancies and births. In 1871, Lord Lister lanced an abscess. In old age, she developed the inevitable troubles of rheumatics, cataract, and bronchitis. Even when well she often consulted her Apothecaries to the Person, and in particular Sir James Reid, Bart., who had been Resident Physician at Balmoral and was for many years her Resident Physician at Windsor. He also attended her in her last illness. There is little doubt that a number of her medical staff never had the opportunity of attending her, especially those in Edinburgh and Dublin. In her reign of sixty-three years, she visited Dublin only on four occasions for brief periods. She seldom visited Edinburgh, but her visits to Balmoral in all totalled seven years. The only unorthodox practitioners on her staff were the Cuppers in London and Edinburgh, but there is no evidence that they ever attended her.

The lists of her attendants contain 218 names, but five appear in two places, so the number of persons is 213. Over the years, the Queen's Medical Household averaged forty to fifty in number. This may seem large, but not in relation to her total Household. In 1866, she was served by a staff of 818 . The Honourable Corps of Gentlemen-at-Arms and the Yeomen of the Guard accounted for 146. The remaining 572 were all engaged in some form of personal service. As there were no motor cars, the Master of the Horse employed 102. It must be remembered that Queen Victoria had for all or part of her reign twelve residences - Buckingham Palace, St. James's Palace, Kensington Palace, Kew Palace, Hampton Court Palace, Windsor Castle, Osborne House, the Marine Pavilion (at Brighton), Claremont House, Holyrood Palace, Balmoral Castle, and Dublin Castle, the major ones, such as Windsor and 


\section{Queen Victoria's Medical Household}

Osborne with a full staff and the rest with a skeleton staff. The Royal Calendar also lists the 247 varieties of tradesmen who catered for her needs.

In conclusion, it should be mentioned that Her Majesty Queen Elizabeth II has a Medical Household of just half the number who served her great-great-grandmother.

\section{ENGLAND}

Physicians

Date of
appointment $\quad \begin{aligned} & \text { Date of } \\ & \text { death }\end{aligned} \quad$ Notes Source

Sir James Clark, Bt.

1837

Sir Henry Halford, Bt.

1837

Sir James McGrigor, Bt.

William Frederick Chambers

1837

Richard Bright

Peter Mere Latham

Neil Arnott

Sir Henry Holland, Bt.

1837

1837

1837

1837

1837

Sir Charles Locock, Bt.

1852

Robert Ferguson

1840

1840

1857

Sir Thomas Watson, Bt.

1859

1870

William Baly

1859

Sir William Jenner, Bt.

Wilson Fox

Sir George Burrows, Bt.

Sir William Withey Gull, Bt.

Sir Edward Henry Sieveking

Charles James Blasius Williams

Sir James Alderson

Arthur Farre

George Owen Rees

Sir James Reid, Bt.

\begin{tabular}{|c|c|c|}
\hline 1870 & $\begin{array}{l}\text { In-Ord. (and } \\
\text { Household) }\end{array}$ & Ld.Ch. \\
\hline 1844 & In-Ord. & R.Cal. \\
\hline 1858 & Extra. & R.Cal. \\
\hline 1855 & In-Ord. & Ld.Ch. \\
\hline 1858 & Extra. & Ld.Ch. \\
\hline 1875 & Extra. & Ld.Ch. \\
\hline 1874 & $\begin{array}{l}\text { Extra. } \\
\text { Extra. }\end{array}$ & $\begin{array}{l}\text { Ld.Ch. } \\
\text { Clip. }\end{array}$ \\
\hline 1873 & In-Ord. & Ld.Ch. \\
\hline 1875 & $\begin{array}{l}\text { Accoucheur } \\
\text { 2nd accoucheur }\end{array}$ & $\begin{array}{l}\text { Ld.Ch. } \\
\text { Ld.Ch. }\end{array}$ \\
\hline 1865 & $\begin{array}{l}\text { Extra. } \\
\text { Extra. }\end{array}$ & $\begin{array}{l}\text { Ld.Ch. } \\
\text { Ld.Ch. }\end{array}$ \\
\hline 1882 & In-Ord. & Ld.Ch. \\
\hline 1861 & $\begin{array}{l}\text { Extra. to help } \\
\text { Sir James Clark }\end{array}$ & Clip. \\
\hline 1898 & Extra. & Ld.Ch. \\
\hline & Extra. & Ld.Ch. \\
\hline 1887 & In-Ord. & \\
\hline & Extra. & Ld.Ch. \\
\hline 188 & $\begin{array}{l}\text { In-Ord. } \\
\text { Extra. }\end{array}$ & $\begin{array}{l}\text { Ld.Ch. } \\
\text { Ld.Ch. }\end{array}$ \\
\hline 1890 & $\begin{array}{l}\text { In-Ord. } \\
\text { Extra. }\end{array}$ & $\begin{array}{l}\text { Ld.Ch. } \\
\text { Ld.Ch. }\end{array}$ \\
\hline 1904 & In-Ord. & \\
\hline 1889 & Extra. & Ld.Ch. \\
\hline 1882 & Extra. & Ld.Cl \\
\hline 1887 & Extra. & Ld.Ch. \\
\hline 1889 & $\begin{array}{l}\text { Extra. } \\
\text { Resident Physician } \\
\text { at Balmoral }\end{array}$ & $\begin{array}{l}\text { Ld.Ch. } \\
\text { Clip. }\end{array}$ \\
\hline & Extra. & Ld.Ch. \\
\hline 192 & $\begin{array}{l}\text { In-Ord. } \\
\text { Resident Physician } \\
\text { at Windsor }\end{array}$ & Ld.Ch. \\
\hline 1925 & $\begin{array}{l}\text { Extra. } \\
\text { In-Ord. }\end{array}$ & $\begin{array}{l}\text { Ld.Ch. } \\
\text { Ld.Ch. }\end{array}$ \\
\hline
\end{tabular}




\section{A. M. Cooke}

Date of
appointment $\begin{gathered}\text { Date of } \\ \text { death }\end{gathered}$ Notes Source

Sir George Johnson

Sir Richard Quain, Bt.

Sir Alfred Baring Garrod

Sir Samuel Wilks, Bt.

Sir William Henry Broadbent, Bt.

James Edward Pollock

Sir Thomas Barlow, Bt.

Sir John Forbes

Francis Hawkins

Sir John Russell Reynolds, Bt.

\section{Surgeons}

Sir Astley Paston Cooper, Bt.

Sir Benjamin Collins Brodie, Bt.

Robert Keate

Benjamin Travers

Thomas Copeland

Sir William Lawrence, Bt.

Henry Earle

Richard Blagden

Ambrose Thomas Sturges Dodd

Sir William Fergusson, Bt.

Caesar Henry Hawkins

Edward Stanley

Sir James Paget, Bt.

James Moncrieff Arnott

Richard Quain

John Hilton

Sir Prescott Gardener Hewett, Bt.

Sir John Eric Erichsen, Bt.

Joseph Lister (later Lord Lister)

Sir William Scovell Savory, Bt.

Sir Thomas Smith, Bt.

Thomas Bryant

Sir Frederick Treves, Bt.

John Phillips

Charles Henry Phillips

Sir Thomas Spencer Wells, Bt.

Sir Rickman Godlee, Bt.
1889

1889

1890

1896

1898

1899

1896

1899

1841

1841
1861

1878

1837

1837

1837

1837

1857

1837

1837

1857

1837

1837

1840

1845

1855

1867

1857

1862

1858

1858

1867

1877

1862

1862

1867

1867

1877

1877

1878

1900

1887

1895

1896

1900

1837

1837

1840

1863

1896
1896 Extra.

1898 Extra.

1907 Extra.

1911 Extra.

1907 Extra.

1910 Extra.

Household

1945 Extra.

Ld.Ch.

Ld.Ch.

Ld.Ch.

Ld.Ch.

Ld.Ch.

Ld.Ch.

Ld.Ch.

Ld.Ch.

Ld.Ch.

Ld.Ch.

Ld.Ch.

1877 Household

1896 Household

1841 Sgt. Surg.

1862 Sgt. Surg.

1857 Sgt. Surg.

Extra.

1858 Sgt. Surg.

1855 Extra.

Extra.

1867 Sgt. Surg.

1838 Extra.

Extra.

1861 Accoucheur

1847 Extra.

Extra.

1877 Sgt. Surg.

Extra.

1884 Sgt. Surg.

1862 Extra.

Extra.

Extra.

1899 Sgt. Surg.

1885 Extra.

1887 Extra.

1878 Extra.

Extra.

1891 Sgt. Surg.

1896 Extra.

Extra.

1912 Sgt. Surg.

1895 Extra.

1909 Extra.

1914 Extra.

1923 Extra.

R.Cal.

R.Cal.

Ld.Ch.

Ld.Ch.

Ld.Ch.

Ld.Ch.

Ld.Ch.

Clip.

Clip.

Ld.Ch.

Ld.Ch.

Obit.

Ld.Ch.

Ld.Ch.

Ld.Ch.

Ld.Ch.

Ld.Ch.

Ld.Ch.

Ld.Ch.

Ld.Ch.

Ld.Ch.

Ld.Ch.

Ld.Ch.

Ld.Ch.

Ld.Ch.

Ld.Ch.

Ld.Ch.

Ld.Ch.

Ld.Ch.

Ld.Ch.

Ld.Ch.

Ld.Ch.

R.Cal.

Ld.Ch.

Ld.Ch.

Ld.Ch. 
Queen Victoria's Medical Household

Date of
appointment $\begin{gathered}\text { Date of } \\ \text { death }\end{gathered} \quad$ Notes Source

Specialist surgeons

Henry Alexander

William White Cooper

1839

1859

1859

Oculist

R.Cal.

George Lawson

William Maule

1886

1837

1886 Oculist

Ld.Ch.

1903 Oculist

Ld.Ch.

1873 Aurist

R.Cal.

Apothecaries

John Nussey

1837

Charles Craddock

1837

Edward Duke Moore

1837

Harry Miller Blaker

Benjamin Vallance

1837

1837

John J. Merriman

1837

John Merriman

1838

James Nathaniel Merriman

1838

William Henry Neville

1840

Sir William Carter Hoffmeister

1845

William Cass

Claudius Francis du Pasquier

1845

1858

James Ellison

1859

Henry Brown

1859

Thomas Fairbank

1866

William Hoffmeister (Junior)

(aged 23)

1867

Sir Francis Henry Laking, Bt.

1874

Sir William Fairbank

1880

1888

1888

William Augustine Ellison

1891

John Bates Hoffmeister

1897

1862

Household and to

Ld.Ch. the Person

1857 Household Clip.

1868 Household and to Ld.Ch. the Person

1846 Brighton

1859 Brighton

1839 Kensington

Ld.Ch.

1881 Kensington R.Cal.

1854 Kensington R.Cal.

? Extra. Ld.Ch.

1890 Osborne Ld.Ch.

1878 Osborne Ld.Ch.

1897 Household and to Ld.Ch. the Person

1897 Windsor Ld.Ch.

1868 Windsor Ld.Ch.

1880 Windsor Ld.Ch.

Henry Edgar William Hoffmeister

1910 Osborne Ld.Ch.

1914 Household and to Ld.Ch. the Person

1929 Windsor

Ld.Ch.

1891 Osborne Ld.Ch.

1917 Windsor Ld.Ch.

1930 Osborne Ld.Ch.

1926 Osborne Ld.Ch.

SCOTLAND

$\begin{array}{ll}\text { Physicians } & \\ \text { John Abercrombie } & 1838 \\ \text { William Pulteney Alison } & 1838 \\ \text { James Home } & 1838 \\ \text { Andrew Combe } & 1838 \\ \text { Robert Spittal } & 1838 \\ \text { John Scott } & 1838 \\ \text { John Thomson } & 1838 \\ \text { Joshua Henry Davidson } & 1844 \\ \text { Sir James Young Simpson, Bt. } & 1847 \\ \text { Sir Robert Christison, Bt. } & 1847 \\ \text { James Warburton Begbie } & 1853 \\ \text { Thomas Laycock } & 1869 \\ \text { Sir William Tennant Gairdner } & 1876\end{array}$

1844 In-Ord.

Ld.Ch.

1859 In-Ord. Ld.Ch.

$\begin{array}{llll}1838 & 1842 & \text { In-Ord. } & \text { Ld.Ch. } \\ 1838 & 1847 & \text { Extra. } & \text { Ld.Ch. }\end{array}$

$1838 \quad 1852$ Extra. $\quad$ Ld.Ch.

$1838 \quad 1853$ Extra. $\quad$ Ld.Ch.

$1838 \quad 1846$ In-Ord. Ld.Ch.

$844 \quad 1847$ In-Ord. $\quad$ R.Cal.

$1847 \quad 1870$ Accoucheur $\quad$ R.Cal.

$1847 \quad 1882$ In-Ord. $\quad$ R.Cal.

$1853 \quad 1876$ In-Ord. Clip.

$1869 \quad 1876$ In-Ord. $\quad$ Ld.Ch.

Sir William Tennant Gairdner

1907 In-Ord.

Ld.Ch. 
A. M. Cooke

\begin{tabular}{|c|c|c|c|c|}
\hline & $\begin{array}{c}\text { Date of } \\
\text { appointment }\end{array}$ & $\begin{array}{l}\text { Date of } \\
\text { death }\end{array}$ & Notes & Source \\
\hline $\begin{array}{l}\text { Sir Thomas Grainger Stewart } \\
\text { George William Balfour }\end{array}$ & $\begin{array}{l}1882 \\
1900\end{array}$ & $\begin{array}{l}1900 \\
1903\end{array}$ & $\begin{array}{l}\text { In-Ord. } \\
\text { In-Ord. }\end{array}$ & $\begin{array}{l}\text { Ld.Ch. } \\
\text { Ld.Ch. }\end{array}$ \\
\hline $\begin{array}{l}\text { George Wood } \\
\text { William Marshall }\end{array}$ & $\begin{array}{l}1837 \\
1872\end{array}$ & $\stackrel{?}{1885}$ & $\begin{array}{l}\text { Apothecary } \\
\text { Resident Medical } \\
\text { Attendant at } \\
\text { Balmoral }\end{array}$ & $\begin{array}{l}\text { R.Cal. } \\
\text { Clip. }\end{array}$ \\
\hline $\begin{array}{l}\text { Surgeons } \\
\text { John Graham Macdonald Burt } \\
\text { Sir George Ballingall } \\
\text { James Syme (in } 1848 \text { he took up } \\
\text { an appointment in London, but } \\
\text { returned to Edinburgh a few months } \\
\text { later). Reappointed } \\
\text { David McLagan } \\
\text { James Miller } \\
\text { James Spence } \\
\text { Joseph Lister (later Lord Lister) } \\
\text { Sir George Husband Baird MacLeod } \\
\text { Sir Patrick Heron Watson } \\
\text { Sir Alexander Ogston }\end{array}$ & $\begin{array}{l}1861 \\
1838 \\
1848 \\
1865 \\
1870 \\
1877 \\
1882 \\
1892\end{array}$ & $\begin{array}{l}1870 \\
1865 \\
1864 \\
1882 \\
1912 \\
1892 \\
1907 \\
1929\end{array}$ & $\begin{array}{l}\text { In-Ord. } \\
\text { In-Ord. } \\
\text { In-Ord. } \\
\text { In-Ord. } \\
\text { In-Ord. } \\
\text { In-Ord. } \\
\text { In-Ord. } \\
\text { In-Ord. }\end{array}$ & $\begin{array}{l}\text { Ld.Ch. } \\
\text { Ld.Ch. } \\
\text { Ld.Ch. } \\
\text { Ld.Ch. } \\
\text { Ld.Ch. } \\
\text { Ld.Ch. } \\
\text { Ld.Ch. } \\
\text { Ld.Ch. }\end{array}$ \\
\hline $\begin{array}{l}\text { Specialist surgeons } \\
\text { William Mackenzie } \\
\text { William Walker } \\
\text { Douglas Moray Cooper Lamb Argyll }\end{array}$ & $\begin{array}{l}1838 \\
1869\end{array}$ & $\begin{array}{l}1868 \\
1885\end{array}$ & $\begin{array}{l}\text { Oculist } \\
\text { Oculist }\end{array}$ & $\begin{array}{l}\text { Ld.Ch. } \\
\text { Ld.Ch. }\end{array}$ \\
\hline $\begin{array}{l}\text { Robertson } \\
\text { Adam Warden }\end{array}$ & $\begin{array}{l}1885 \\
1845\end{array}$ & $\begin{array}{l}1909 \\
1850\end{array}$ & $\begin{array}{l}\text { Oculist } \\
\text { Aurist }\end{array}$ & $\begin{array}{l}\text { Ld.Ch. } \\
\text { Ld.Ch. }\end{array}$ \\
\hline
\end{tabular}

IRELAND

Physicians

Sir Henry Marsh, Bt.

Sir Dominic Corrigan, Bt.

Thomas Lewis Monaghan

Robert Law

John Hughes

George William Hatchell

(see also under Surgeons)

Edward Ward Walter Raleigh

William Stokes

E ... F ... Burke

J ... Nealey

Thomas Nedley

1838
1838

1838

1861

1865

186

1882

1912

1892

1907

1929

1850 Aurist
R.Cal.

Ld.Ch.

Ld.Ch.

Ld.Ch.

Ld.Ch.

Ld.Ch.

d.Ch.

Ld.Ch.

Ld.Ch.

Ld.Ch.

Ld.Ch.

(There is some doubt about whether he was a Physician or a Surgeon)

William Malachi Burke

Alfred Hudson

1837

1847

1849

1851

1856

1857

1859

1861

1867

1871

1872

1875

1878
1860 In-Ord.

1880 In-Ord.

1857 In-Ord.

1875 In-Ord.

1882 In-Ord.

1890 In-Ord.

1865 Household

1878 In-Ord.

? In-Ord.

? In-Ord.

1899 In-Ord.

1879 In-Ord.

1880 In-Ord.
Cameron

Ld.Ch.

R.Cal.

R.Cal.

R.Cal.

Cameron

Plarr

Ld.Ch.

R.Cal.

R.Cal.

Cameron

Cameron

Ld.Ch. 
Queen Victoria's Medical Household

Date of
appointment $\quad \begin{gathered}\text { Date of } \\ \text { death }\end{gathered} \quad$ Notes Source

Sir John Thomas Banks

Benjamin George MacDowel

Sir Christopher John Nixon, Bt.

William Moore

Walter George Smith

Sir Francis Cruise

\section{Surgeons}

Sir Philip Crampton, Bt.

John Francis Purcell

Gerard Macklin

James O'Beirne

George William Hatchell

(see also under Physicians)

James Stannus Hughes

James William Cusack

Robert Adams

Sir George Hornidge Porter, Bt.

John Hamilton

William Colles

Edward Dillon Mapother

Robert McDonnell

Richard Francis Tobin

Sir Arthur Chance

Sir William Stokes

Sir Kendal Mathew St.John Franks

Sir Philip Crampton Smyly

Edward Hamilton

Sir John Lentaigne

Sir William Thomson

Specialist surgeons

Sir William Robert Wills Wilde $\quad 1854$

Charles Edward Fitzgerald

Archibald Hamilton Jacob

Apothecaries

Henry Hunt

John James Parr

Daniel Pakenham
1880

1881

1881

1885

1896

1901

1837

1838

1838

1838

1838

1856

1859

1861

1869

1875

1875

1880

1881

1892

1892

1892

1892

1895

1897

1899

1900

1854

1883

1838

1849

1849

$\begin{array}{ll}1908 & \text { In-Ord. } \\ 1885 & \text { In-Ord. } \\ 1914 & \text { In-Ord. } \\ 1901 & \text { In-Ord. } \\ 1932 & \text { In-Ord. } \\ 1912 & \text { In-Ord. }\end{array}$

Ld.Ch.

Ld.Ch.

Cameron

Ld.Ch.

R.Cal.

Clip.

Cameron

Cameron

Cameron

1848 In office from 1806

1862 Extra.

1890 In-Ord.

Ld.Ch.

Cameron

1884 Household

1861 In-Ord.

1875 In-Ord.

1895 In-Ord.

1875 In-Ord.

1892 In-Ord.

1908 In-Ord.

1889 In-Ord.

1919 In-Ord.

1928 In-Ord.

1900 In-Ord.

1920 In-Ord.

1904 In-Ord.

1899 In-Ord.

1915 Household

1909 In-Ord.

Cameron

Ld.Ch.

Ld.Ch.

Ld.Ch.

Ld.Ch.

Ld.Ch.

Obit.

R.Cal.

Med. Dir.

Cameron

Ld.Ch.

R.Cal.

Ld.Ch.

Cameron

Cameron

Ld.Ch.

Ld.Ch.

Ld.Ch.

Cameron

Cameron

R.Cal.

R.Cal.

\section{Miscellaneous}

Baron Christian Frederick Stockmar (d. 1863) was a member of the Royal Household and for the first twenty years of Victoria's reign was intermittently political adviser and sort of private secretary. He had been Physician to Prince Leopold of Coburg, but did not attend the Queen medically. 


\section{A. M. Cooke}

John Snow (d. 1858) gave the Queen chloroform in 1853 for the birth of the Duke of Albany, and again in 1857 for the birth of Princess Beatrice. He does not appear to have had any appointment to the Medical Household.

Dr. von Aschen was appointed Island Physician in Heligoland in 1858 (Ld.Ch.).

George Vivian Poore (d. 1904) appears in the list of the Queen's Household for 1871, as Tutor and Medical Attendant to HRH Prince Leopold.

Harrington Sainsbury (d. 1936) was for one year Assistant Physician at Windsor Castle.

Robert McCormick (d. 1890) was Surgeon to the Royal Yacht (William and Mary) 1845-1847 (Plarr).

John Moolenburgh Minter (d. 1891) was also Surgeon to the Royal Yacht.

\section{Honorary Physicians and Surgeons}

This rank was promulgated by an Order in Council of 13 May 1859. Those selected were medical men who had served with distinction in the Royal Navy, Army, Indian Medical Service or Public Health. They had no medical duties, but appear to have been part of the Medical Household. Nearly all were appointed in and after 1859, but one, Robert Roddam was appointed by William IV and continued into Victoria's reign (R.Cal.). This is almost certainly an error, and it should be George Roddam, a Naval Surgeon who died in 1838 (Navy List).

\begin{abstract}
Alexander Bryson
Charles Morehead

Sir Joseph Fayrer, Bt.

Sir William Guyer Hunter

Sir Alexander Armstrong

Sir James John Louis Donnet

Sir James Jenkins

Dugald McEwan

Richard Denton Mason

John Moolenburgh Minter

David Lloyd Morgan

Timotheus Haran
\end{abstract}

\begin{tabular}{|c|c|c|c|}
\hline Date of & Date of & Notes & Source \\
\hline 1859 & 1869 & R. Navy & DNB \\
\hline 1861 & 1882 & India & DNB \\
\hline 1871 & 1907 & India & Munk \\
\hline 1880 & 1902 & India & Munk \\
\hline 1889 & 1899 & R. Navy & R.Cal. \\
\hline 1889 & 1905 & R. Navy & R.Cal. \\
\hline 1889 & 1912 & R. Navy & R.Cal. \\
\hline 1889 & 1904 & R. Navy & R.Cal. \\
\hline 1889 & 1894 & R. Navy & R.Cal. \\
\hline 1889 & 1891 & R. Navy & R.Cal. \\
\hline 1889 & 1892 & R. Navy & R.Cal. \\
\hline 1889 & 1904 & R. Navy & R.Cal \\
\hline
\end{tabular}

Dentists

It is often impossible to find any biographical details about the Dentists, but the following incomplete list is appended.

Charles Dumergue

Charles Bew

Alexander Nasmyth

John Jones

Sir Edwin Saunders

Edwin Thomas Trumañ

Alfred Alabone

Edward Moore

\section{ENGLAND}

1837

1841

1845

1847

1847

1855

1864

1865

$\begin{array}{cll}? & \text { In.Ord. } & \text { Ld.Ch. } \\ 1855 & \text { Household } & \text { R.Cal. } \\ 1848 & \text { In-Ord. } & \text { Ld.Ch. } \\ ? & \text { Cambridge } & \text { Ld.Ch. } \\ 1901 & \text { In-Ord. } & \text { Ld.Ch. } \\ ? & \text { Household } & \text { Ld.Ch. } \\ ? & \text { Osborne } & \text { Ld.Ch. } \\ ? & \text { Windsor } & \text { Ld.Ch. }\end{array}$

\section{SCOTLAND}

David Wemyss Jobson

Robert Nasmyth

John Smith
1838

1839

1871

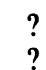

1910
Ld.Ch.

R.Cal.

Ld.Ch. 


\section{Queen Victoria's Medical Household}

Date of
appointment $\begin{gathered}\text { Date of } \\ \text { death }\end{gathered} \quad$ Notes Source

Heary Hudson

Samuel George Hutchins

P. Brophy

F. Maclean

Francis L'Estrange

Sir George L'Estrange

Robert Moore

Daniel Corbett

IRELAND

1838

1839

1843

1857

1849

1863

1878

1881
R.Cal.

Ld.Ch.

R.Cal.

R.Cal.

R.Cal.

R.Cal.

R.Cal.

R.Cal.

\section{Paramedical}

John Mapleson was appointed Cupper in England in 1837.

Jonathan Duncan Kerr was appointed Cupper in Scotland in 1838.

(There was also a State Cupper in Dublin up to 1833).

Lewis Durlacher was appointed Surgeon Chiropodist in 1837.

Montague Durlacher, his son, succeeded him in the same office in 1879.

Michael La Beaume was appointed Medical Galvanist and Electrician in 1839.

George Combe, phrenologist and educationist, in 1850, examined the head of the Prince of Wales, then aged nine years, because the Prince was doing badly at his lessons. Combe was not a medical man, but a lawyer, a Writer to the Signet in Edinburgh, although he devoted himself wholly to phrenology.

Madame Charlotte Nautet, from Aix-les-Bains, was appointed Masseuse (or Rubber) in 1883.

Pharmacists

Date of Source
appointment

ENGLAND

"Mr. Squire"

Sir Peter Wyatt Squire and Peter Squire

1837

1868

1877 Ld.Ch.

Clip.

Sir Peter Wyatt Squire and Alfred Herbert Squire

(The Squire family were Pharmacists to the Queen from her accession to her death.)

\section{SCOTLAND}

Duncan, Flockhart \& Co.

J. F. Macfarlan
1850 R.Cal.

1852 R.Cal.

\section{IRELAND}

Bewley, Evans \& Co.
John Evans

Hamilton, Oldham \& Co.
1869 Clip.

1874 R.Cal. 
SUMMARY

Lists of Queen Victoria's Physicians, Surgeons, Apothecaries, Dentists, Paramedical staff, and Pharmacists are given, with dates of appointment and date of death, where known. There is a brief account of methods of their selection, appointment, payment, and position in the Royal Household.

\section{ACKNOWLEDGEMENTS}

It is a pleasure to acknowledge my indebtedness and express my thanks to those who have given permission for the use of material, provided information, and helped me in other ways. They include the Staff of the Public Record Office; Sir Robin Mackworth-Young, K.C.V.O., and Miss Jane Langton, C.V.O., of the Library, Windsor Castle; Mr. R. D. McLaren of the General Medical Council; Mr. D. N. Cole, Librarian, and Miss Terry Parker, Archivist, of the Royal College of Physicians of London; Mr. E. Cornelius, Librarian of the Royal College of Surgeons of England; Miss Joan Ferguson, Librarian of the Royal College of Physicians of Edinburgh; Miss Dorothy U. Wardle, Librarian of the Royal College of Surgeons of Edinburgh; Dr J. B. Lyons and Mr. Robert W. Mills, Assistant Librarian of the Royal College of Physicians of Ireland, Miss E. M. Spencer, Librarian of the British Dental Association; Mr P. J. R. Warren of the Radcliffe Science Library, Oxford; Mr. A. J. Francis of the Naval Historical Library, Ministry of Defence; Sir Ronald Bodley Scott, G.C.V.O., F.R.C.P.; Professor Charles Phillips, F.R.C.P., F.R.S.; and the late Sir Derrick Dunlop, F.R.C.P. 